\title{
ABCA7 wt Allele
}

National Cancer Institute

\section{Source}

National Cancer Institute. ABCA7 wt Allele. NCI Thesaurus. Code C162366.

Human ABCA7 wild-type allele is located in the vicinity of $19 \mathrm{p} 13.3$ and is approximately 25 $\mathrm{kb}$ in length. This allele, which encodes phospholipid-transporting ATPase ABCA7 protein, is involved in phagocytosis of apoptotic cells by macrophages and lipid transport.

Deletion and nonsense mutations in the gene are associated with susceptibility to Alzheimer disease type 9. 